\title{
ON THE SULFIDES IN THE SEDIMENTS OF THE BOTHNIAN SEA
}

\author{
Heikki Papunen \\ Institute of Geology, University of Turku, Finland
}

\begin{abstract}
Sediments starting with the Ancylus stage of the Baltic up to the Litorina stage contain considerable amounts of sulfide. Sulfide minerals of six samples were studied microscopically, chemically and by X-rays. Framboidal pyrite spherules occur in the sulfide-rich sediments whereas those with only sparse sulfide are black and contain pigmentous amorphic sulfide incorporated with colloids. Also marcasite-bearing framboidal spherules were verified. The chemical composition of the sulfides and also the size frequency distribution of the framboids are presented with diagrams.
\end{abstract}

\section{Introduction}

Some of the sediment beds in the Baltic Sea are sulfur-bearing. These sediments, also called sapropels, have been described e.g. by Gripenberg (1934) and Manheim (1961). Also analogous sediments in the area of land uplift, Bothnia, have been reported by Purokoski (1958). However, the mineralogy of sulfides has not yet been described.

The present author obtained some samples of sulfide-bearing sediments for mineralogical study from Mr H. Ignatius Ph. D. and Mr Esa Kukkonen M. Sc. of the Geological Survey of Finland. Samples were taken by a Kullenberg piston corer during the Baltic cruises of the Finnish research vessel M/S Aranda. Six samples from the eastcentral part of the Bothnian Sea from two coring stations numbered M 5/66 and M 16/66 were studied microscopically, chemically and by $\mathrm{X}$-rays. The aim of this study is to clarify the mineralogy and distribution of sulfides in these samples.

\section{Occurrence}

The general stratigraphic sequence of the Baltic sediments has been described e.g. by Ignatius (1958, 1964) and Hyyppä (1964). According to Ignatius (1964), a black, often layered sulfide-bearing bed occurs in homogenous gray clay. The black bed belongs to "Lower Ancylus» sediments. Another black bed is sometimes met with at the top of the sediment series belonging to the Post-Litorina sediments. This upper sulfide-bearing bed exists especially in areas of the Northern Baltic Sea, the Gulf of Finland and the Gulf of Bothnia. According to the investigations of the marine expedition, both of these black beds are sulfur-bearing and thus have been called sulfide-clays. The gray and greenish-gray gyttja between them has also been verified as sulfur-bearing but the lack of black colour has lead to the opinion that in this case sulfur is either in the form of sulfate or elementary sulfur.

The samples studied here belong to two cores. One of them, M 5/66, is almost complete, con- 
taining 5 samples, whereas only one sample from core M 16/66 has been studied. Table 1 gives the number, core (coring station), depth and general stratigraphic positions of the samples.

TABLE 1

\begin{tabular}{|c|c|c|c|c|}
\hline No & core & $\begin{array}{c}\text { depth below } \\
\text { bottom of the } \\
\text { sea }\end{array}$ & $\begin{array}{l}\text { stratigraphic } \\
\text { position }\end{array}$ & colour \\
\hline 1 & M 5/66 & $15-30 \mathrm{~cm}$ & Litorina & olive \\
\hline 2 & $»$ & $43-52 »$ & Litorina & dark olive \\
\hline 3 & $》$ & $54-66 »$ & „Upper» Ancylus & gray \\
\hline 4.a & 》 & $90-95 »$ & "Lower" Ancylus & black \\
\hline 4.b & M $16 / 66$ & $105-113$ & $»$ & black \\
\hline 5 & M 5/66 & $105-120 »$ & Yoldia & gray \\
\hline
\end{tabular}

\section{Description of the samples}

On the basis of microscopic examination and external characteristics the samples were grouped as follows: samples 1,2 and 3 are gyttjas with small opaque spherules, 4.a and 4.b are black clays and sample 5 represents gray clay.

Gyttja with opaque spherules: these sediments are gray or olive green in natural humidity. Special microscopic features are the opaque spherules, the size of which ranges from $1 \mu$ to $30 \mu$. Polished sections were made from dried samples by impregnating the samples with Araldit-resin. In reflected light the framboidal textures of the spherules are clearly visible. The spherules consist of small idiomorphic pyrite crystals, which often are completely disordered. Very exceptionally, ordered framboids can also be seen. In addition to crystal spherules, also idiomorphic single pyrite crystals occur abundantly (Fig. 1). The framboidal texture has recently been thoroughly described e.g. by Love and Amstutz (1966) who also present a complete list of references. The same textural features they described concerning the Chattanooga shale and the Rammelsberg Bandertz can also be found in these framboids. But, in addition, a special feature, which they did not report, can be seen in sample 3. This texture is illustrated in Figs. 2 and 3. The spherules are mostly zonal. The

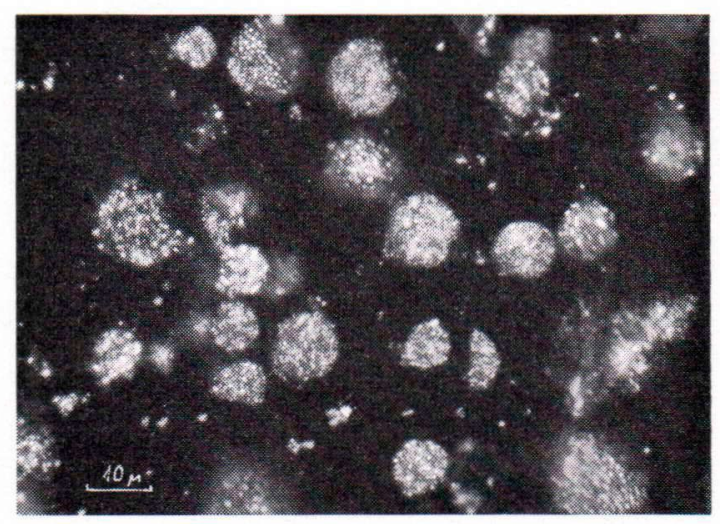

Fig. 1. Framboidal pyrite spherules in sample 2. Reflected light, oil immersion.

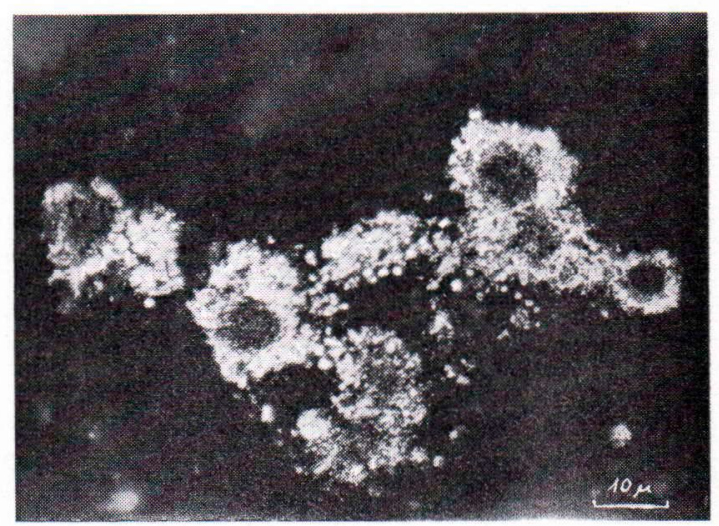

Fig. 2. Zonal spherules in sample 3. Polished section oil immersion.

»normal» framboids with very small pyrite crystals exist as cores on which there are small radially ordered prismatic crystals (Fig. 3 a). The optics resemble that of marcasite and the $\mathrm{X}$-ray study, described in the following pages, confirms the mineral as marcasite. In this sample, the sulfide accumulations are not as regularly rounded as in samples 1 and 2 but are irregular as those in Figs. $3 \mathrm{~b}$ and c. Some of them are composed of marcasite and can contain framboidal pyrite spherules inside accumulations (Fig. 3 b). Fig. 4 depicts the frequency distribution of the size of the framboids in samples 1 and 2. The diameters were measured from pol- 

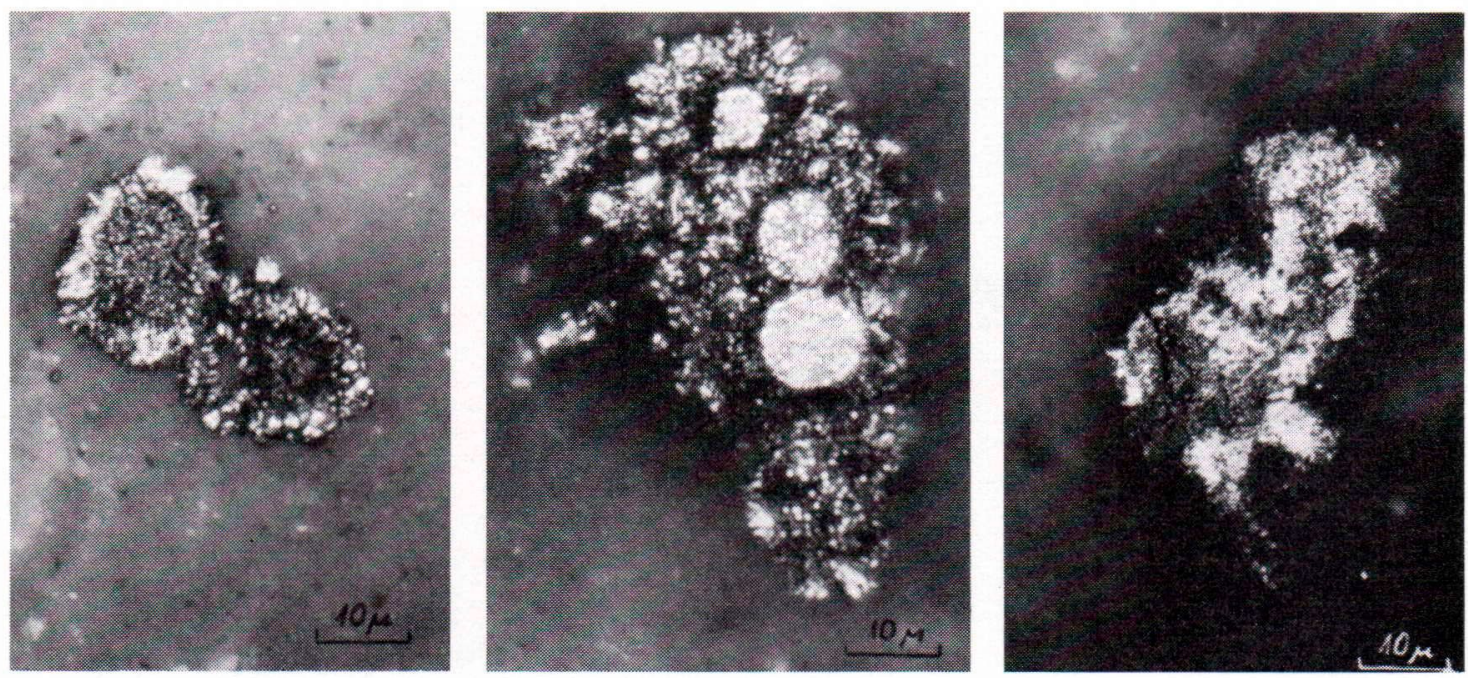

Fig. 3. Sulfide accumulations in sample 3. In Fig. 3 a the zonality of spherules can be seen; core is pyrite and margins marcasite. Fig. 3. b represents a marcasite accumulation containing pyrite framboids in the nucleus. In Fig. 3. $c$ there is an irregular pyrite accumulation with marcasite margins. Polished sections.

ished sections by an ocular-micrometer. As the framboids with a diameter below $1.5 \mu$ can no longer be distinguished with certaintly from single pyrite crystals, not even with great magnification and oil immersion, the data below $2 \mu$ has not been given in the diagram. The more general distribution is very similar in both samples - between 3-8 $\mu$. In sample 1 it is a little higher. There is a clear downthrow in smaller diameters and the distribution is unimodal. The distributions seem to be positively skewed, again in sample 1 more than in 2 , and it is possible that they approximate lognormal distribution. The results agree well with those obtained from the Chattanooga shale and the Rammelsberg Bandertz described by Love and Amstutz (1966).

B l a ck cla ys: Samples 4.a and 4.b are smearlike and almost black in natural humidity. Under the influence of the atmosphere they turn to gray in a few hours, after which they resemble the other samples in colour. A brown, limonitelike film develops simultaneously on the surfaces. In a fresh sample one can observe microscopically roundish or irregular blobs (Fig. 5), the

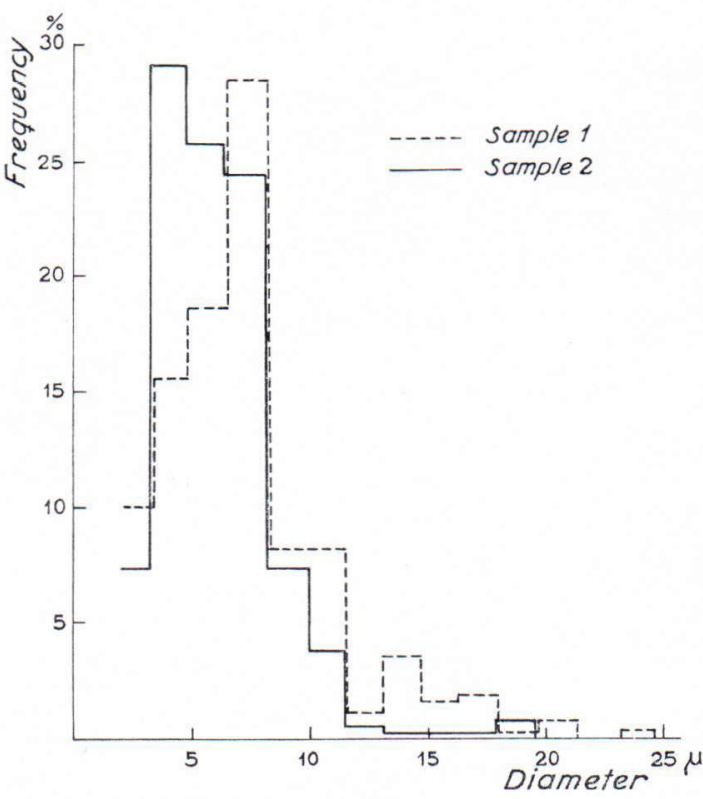

Fig. 4. Size frequency distribution of framboids in samples 1 and 2 .

sizes of which vary greatly. The blobs are stained by black pigment but are, however, translucent at the margins. A jelly-like material 


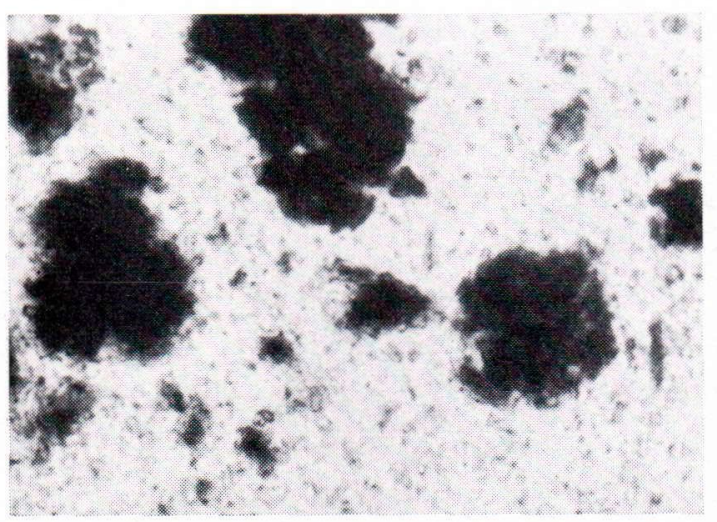

Fig. 5. Blobs of colloidal matter stained by black pigment in sample 4. Transmitted light.

is thus the base of the black pigment. If the sample is suspended in water, the more coarse detritus and clayey matter settle in a few hours but water above it remains black for weeks disturbed by pigmentous colloid. Framboidal pyrite spherules were not detected by transmitted or reflected light and separation with heavy liquids did not give sulfides in the heavy fraction.

G r a y c l a y: Sample 5 differs from the other samples due to the fact that it does not contain framboidal spherules or black, pigmentous jellylike material as the other samples do. It represents the ordinary Yoldia clay below sulfidebearing sediments.

\section{X-ray study}

The Debye-Scherrer diagrams were made from the heavy fractions separated by Clerici solution $(\mathrm{d}=3.80)$ from samples 1,2 and 3 . Only reflexes of pyrite were detected in the powder pattern of samples 1 and 2 . The cell edge of pyrite was observed to be $5.419 \pm 0.003 \AA$.

The debyeograms of the sulfides in sample 3 show lines of pyrite in addition to those of marcasite. The latter is characterized e.g. by the lines of $\mathrm{d}=3.43,2.315,1.755$ (strong), 1.720, $1.689,1.595$ and $1.430 \AA$, which do not occur in the diagrams of pure pyrite. X-ray study thus verifies the microscopic observations concerning the occurrence of marcasite.

Several X-ray photographs were taken from the black pigmentous jelly-like matter of sample 4.a. The reflections of sheet silicates, such as $\mathrm{d}=14.0 \AA, 10.0 \AA$, and $7.0 \AA$, occur in every debyeogram but no lines characterizing pyrite or marcasite can be seen. The weak, very diffuse bands with d-values of about $5.0 \AA$ and $3.0 \AA$ possibly indicate mackinawite (Berner, 1962). The total X-ray diffraction pattern was measured from each sample. Table 2 lists the measured d-values and their intensities. According to it the most common minerals are the sheet silicates, chlorite and illite of the clay mineral group, but also quartz and feldspars occur in abundance. Minerals of the montmorillonite group do not exist, because lattices with a d-value of $14.0 \AA$ did not expand under glycol treatment. As the intensities of the reflections are proportional to the amounts of minerals in the samples, it is evident that all the samples have very similar mineral compositions.

TABle 2

\begin{tabular}{c|r|r|r|r|r|r|l}
\hline & \multicolumn{6}{|c|}{ intensities = 100 I/Imax } & \\
\cline { 2 - 5 } & $\begin{array}{c}\text { sample } \\
1\end{array}$ & $\begin{array}{c}\text { sample } \\
2\end{array}$ & $\begin{array}{c}\text { sample } \\
3\end{array}$ & $\begin{array}{c}\text { sample } \\
4 . a\end{array}$ & $\begin{array}{c}\text { sample } \\
4.6\end{array}$ & $\begin{array}{c}\text { sample } \\
\text { mineral }\end{array}$ & \\
\hline 14.0 & 13 & 24 & 26 & 28 & 14 & 19 & Chl (001) \\
9.95 & 69 & 72 & 86 & 96 & 59 & 89 & Ill \\
8.3 & 8 & 10 & 14 & 19 & - & 19 & Chl \\
7.75 & 5 & - & - & - & - & 19 & \\
7.03 & 40 & 48 & 57 & 52 & 35 & 52 & Chl (002) \\
4.95 & 11 & 3 & 14 & 15 & 10 & 15 & Ill \\
4.70 & 11 & 7 & 9 & 11 & - & 11 & Chl (003) \\
4.45 & 3 & - & - & 7 & - & 7 & Ill \\
4.22 & 16 & 17 & 14 & 19 & 17 & 15 & Q \\
4.00 & 8 & 10 & 6 & 11 & 10 & 11 & Feldspar \\
3.75 & 11 & 7 & 11 & 15 & 7 & 15 & Feldspar \\
3.52 & 26 & 28 & 26 & 30 & 20 & 30 & Chl, Ill \\
3.47 & 13 & 7 & 11 & 22 & 20 & 22 & \\
3.33 & 100 & 100 & 100 & 100 & 100 & 100 & Q, Ill, Feld \\
3.22 & 24 & 20 & 26 & 33 & 24 & 26 & Plag \\
3.17 & 34 & 35 & 29 & 52 & 48 & 44 & Feldspar \\
3.12 & 8 & 14 & 6 & 11 & - & 11 & Ill \\
2.91 & 5 & 7 & - & 9 & 7 & 11 & Ill \\
2.82 & 5 & 3 & - & 4 & 10 & 7 & Ill \\
& & & & &
\end{tabular}

$\mathrm{Chl}=$ chlorite-group

$\mathrm{IIl}=$ illite-group

$\mathrm{Q}=$ quartz

Feldspar = potash feldspar

$\mathrm{Plag}=$ plagioclase 


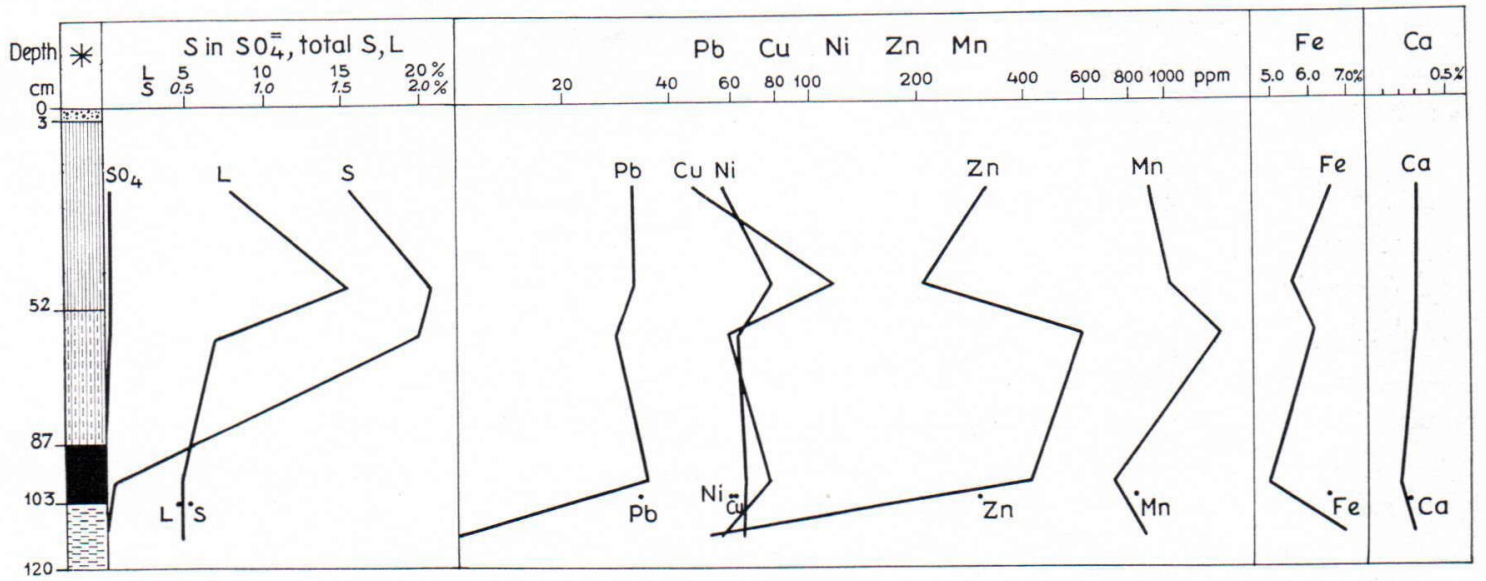

Fig. 6. Diagram representing the variations of chemical composition in the studied samples. Black spots indicate composition of sample 4 . b, which does not belong to the same core as the other samples. Stratigraphic sequence of the core M 5/66 according to Esa Kukkonen: $0-3 \mathrm{~cm}$ loose fine sand; $3-52 \mathrm{~cm}$ olive green gyttja, lower part dark olive; $52 \mathrm{~cm}$ boundary between Litorina and Ancylus; $52-87 \mathrm{~cm}$ gray Ancylus-gyttja, transitional zone to sulfide clay at the bottom; 87-103 cm black clay; $103 \mathrm{~cm}$ Ancylus - Yoldia boundary; 103- Yoldia clay.

$\mathrm{L}=$ loss on ignition

* = stratigraphy

Table 3.

Chemical composition of the samples. Analyses by the author.

\begin{tabular}{|c|c|c|c|c|c|c|c|c|c|c|c|}
\hline Sample & $\begin{array}{c}\mathrm{S} \\
\mathrm{SO}_{4} \\
\%\end{array}$ & $\begin{array}{c}\mathrm{S} \\
\text { total } \\
\%\end{array}$ & $\begin{array}{l}\mathrm{L} \\
\%\end{array}$ & $\begin{array}{l}\mathrm{Fe} \\
\%\end{array}$ & $\begin{array}{c}\mathrm{Mn} \\
\%\end{array}$ & $\begin{array}{l}\mathrm{Ca} \\
\%\end{array}$ & $\underset{\mathrm{ppm}}{\mathrm{Cu}}$ & $\begin{array}{c}\mathrm{Pb} \\
\mathrm{ppm}\end{array}$ & $\begin{array}{c}\mathrm{Zn} \\
\mathrm{ppm}\end{array}$ & $\underset{\mathrm{ppm}}{\mathrm{Ni}}$ & $\begin{array}{c}\text { Co } \\
\mathrm{ppm}\end{array}$ \\
\hline $1 \ldots$ & 0.05 & 1.65 & 8.06 & 6.50 & 0.09 & 0.36 & 48 & 32 & 314 & 57 & 26 \\
\hline $2 \ldots$ & 0.04 & 2.16 & 15.31 & 5.59 & 0.10 & 0.33 & 118 & 32 & 207 & 78 & \\
\hline $3 \ldots$ & 0.05 & 1.99 & 6.69 & 6.16 & 0.15 & 0.33 & 59 & 28 & 587 & 63 & \\
\hline $4 . a$ & - & 0.06 & 4.87 & 5.02 & 0.07 & 0.20 & 76 & 35 & 421 & 64 & \\
\hline $4 . b \quad \ldots$ & - & 0.55 & 4.30 & 6.63 & 0.08 & 0.32 & 60 & 34 & 304 & 60 & \\
\hline 5 & - & - & 4.78 & 6.95 & 0.09 & 0.37 & 55 & 4 & 50 & 64 & \\
\hline
\end{tabular}

$\mathrm{L}=$ loss on ignition

\section{Chemistry}

Table 3 and Fig. 6 present the chemical composition of the samples.

First of all, the sulfur soluble in water was determined in all of the samples $\left(\mathrm{SO}_{4}\right.$-sulfur in Table 3). Then the sample was treated with brominated nitric acid and sulfur, iron, manganese, calcium, copper, lead, nickel and zinc were determined from this solution. Sulfur was determined gravimetrically and all the cations with an atomic absorption spectrophotometer
(Perkin-Elmer). The percentages were calculated from the weights of the dried samples. The loss on ignition was determined by heating the dried sample to $650^{\circ} \mathrm{C}$.

$\mathrm{Sulfur}$ : The total sulfur content is most abundant in samples $1-3$ which contain framboidal pyrite and marcasite spherules. In samples $4 . a$ and $4 . b$ the sulfur content is distinct but not so considerable as in samples $1-3$. According to Kaplan et. al. (1963), at least $50 \%$, mostly over 80 per cent of the sulfur occurring 
in marine sediments is in the form of iron sulfides. Sulfur soluble in water occurs in samples as sulfate ion or as free hydrogen sulfide.

The c a l ci u m-content $\left(\mathrm{HNO}_{3}\right.$-soluble) is almost constant in every sample and it is possibly dependent on the $\mathrm{CaCO}_{3}$-content of the samples.

The percentage of iron varies slightly but not parallel to the sulfur content. Due to the high iron content, it is also evident that the iron dissolved in brominated nitric acid originates, not only from sulfides, but also from hydroxides and sheet silicates (chlorite-group). The correlation between iron and manganese is evident and is probably due to the similarity of the hydroxides. The chalcophile elements, copper, lead and zinc, are more abundant in sediments with a high sulfur content. Especially lead and zinc are correlative with sulfur. The nickel-content however does not vary parallel to the sulfur-content.

The loss on ignition is two or three times higher in the samples with a high sulfurcontent than in those with low sulfur. The loss on ignition is dependent on the loss of water, which is chemically bound in minerals, on the oxidation of sulfides to volatile $\mathrm{SO}_{2}$ and on the oxidation of the organic matter. As the mineral compositions of all the samples are very similar, it is probable that also the amounts of chemically bound water are equal. The maximum percentage of sulfur was about 2 per cent. Thus the oxidation of sulfur alone does not explain the variations in the loss on ignition, but it is generally dependent on the variations in the percentages of the organic substances.

\section{Discussion}

Pyrite seems to be the most abundant sulfide in the samples described here. It generally occurs as framboidal spherules but also single crystals exist. The richest sulfide bed is underlain by a layer containing marcasite in addition to pyrite. Below this there is a stratum, which is coloured black by pigmentous monosulfide incorporated with colloids. This black bed has so far been regarded as a real sulfide horizon. According to this study, however, it is a transitional zone between the sulfide-rich sediment containing pyrite and marcasite and the sediment without sulfides (sample 5). Monosulfides are metastable in oxidating environments as e.g. under the influence of the atmosphere and they evidently turn to ferric hydroxide and to elemental sulfur or sulfates. Occasionally also another black sulfide bed overlies the pyrite rich bed.

According to this study the amount of organic matter is correlative with the sulfide content of the sediment. Thus it seems apparent, that sulfide-sulfur was at least partly biogenic and liberated by the action of sulfur-bacterias. Hydrogen sulfide is also liberated by bacterial reduction of the sulfate ion in marine water as proposed e.g. by Manheim (1961). The bacterial decomposition of sulfur-bearing organic compounds or sulfate ions could have happened in a deposited sediment or during deposition at the sedimentwater interface. The gradual change from a sulfide-rich sediment into a non sulfurous stratum with an unstable transitional form both above and beneath the sulfide rich horizon indicates, however, that formation of sulfides had taken place at least partly, perhaps completely, in the deposited sediment series.

In the opinion of the present author the iron, which reacts with sulfide ion, is bound in organic compounds, possibly in humic acids occurring as colloids in water and sediments. The iron is bound in humic colloids so weakly that it is still reactive e.g. with sulfide ion, or the bond has weakened because of increasing acidity and coacervation of the colloid. If there is not enough sulfur to form stable disulfides, black pigmentous monosulfide forms and remains combined with colloids as in samples 4.a and 4.b. The extra sulfide ions cause an increase in acidity in the system and therefore the colloids coacer- 
vate and framboidal pyrite then forms in the coacervate drops.

The textures of the sulfide spherules and the monosulfide pigments presented here confirm the colloidal origin of framboids which has been previously discussed by the present author $(\mathrm{Pa}-$ punen 1966). The matrix body or matrix body in a sack described by Love and Amstutz (1966) as a residue of the framboidal pyrite spherule after nitric acid treatment was thus the primary colloid which carried the pyrite forming iron and which coacervated during the crystallization of the pyrite.

The enrichment of elements such as lead, zinc and copper in the sulfide-rich horizon may be due to the biophile character of the elements. Another possible explanation of the enrichment is the absorption of chalcophile metals in clay and ferric hydroxide in fresh water environments and desorption of metals during sulfide precipitation in saline reducing environments. This has been experimentally proved by Temple and LeRoux (1964). Complex framboids containing both pyrite and marcasite have not so far been reported. However, the existence of marcasite around pyrite framboids in sample 3 is unambigous. The acidity of the system is regarded as a factor determining the mode of crystallization of pyrite and its dimorph marcasite. In wet chemical syntheses weakly acid, neutral or alkaline conditions favour the formation of pyrite, whereas in strongly acid conditions marcasite is formed (Deer, Howie, Zussman 1962). According to Degens (1965) geologic field data also indicate that marcasite is widespread in fresh water environments which are acid in nature, whereas pyrite is abundant in marine sediments that provide neutral or alkaline environments.

As the samples described here represent only a minute part of the sediments of the whole Bothnian Sea, the results of this study are only preliminary. The mineralogy and external characteristics of sulfides described here, however, form basic concepts for the study of the distribution and stratigraphic sequence of sulfurbearing sediments.

Acknowledgements - The author is indebted to Mr Heikki Ignatius Ph.D. and to Mr Esa Kukkonen M.Sc, who kindly placed the samples at the authors disposal. Mr Heikki Ignatius also read the manuscript and made valuable suggestions. The figures were drawn by Mrs Lyyli Orasmaa. The financial aid of the Foundation of Outokumpu Co (Outokumpu Oy:n Säätiö) made this study possible.

\section{REFERENCES}

Berner, R. A. (1962). Tetragonal FeS, a new iron sulfide. Science, 137, 669.

Deer, W. A. - Howie, R. A. - Zussman, J. (1963). Rock Forming minerals Vol. 5, Longmans, London.

DEgens, EgON T. (1965). Geochemistry of Sediments. A Brief Survey, Prentice-Hall Inc. New Jersey.

Gripenberg, Stina (1934). A Study of the Sediments of the North Baltic and Adjoinig Seas. Fennia 60, No 3.

HYyppä, EsA (1964). On the Late-Quaternary History of the Baltic Sea, Fennia 89, No 1.

IgNATIUS, Heik KI (1958). On the rate of sedimentation in the Baltic Sea, Bull. Comm. géol. Finlande No 180.

Ignatius, Heikni (1964). Merigeologiaa Itämeren piirissä, Natura No 1, Helsinki (Finnish).

Kaplan, I. R. - Emery, K. O. - RittenberG, S. C. (1963). The distribution and isotopic abundance of sulfur in recent marine sediments off southern California, Geoch. Cosmoch. Acta 27, 297-331.
Love, L. G. and Amstutz, G. C. (1966). Review of Microscopic Pyrite. Fortschr. Mineralogie 43, 273-309.

MANHeim, Frank T. (1961). A geochemical profile in the Baltic Sea. Geoch. Cosmoch. Acta 25, 52-70.

Papunen, Heikmi (1966). Framboidal texture of the pyritic layer found in a peat bog in SE-Finland, C.R. Soc. géol. Finlande XXXVIII, pp. 117-125.

Purokoski, PaAvo (1958). Die schwefelgehaltige Tonsedimente in dem Flachlandgebiet von Liminka im Lichte chemischer Forschung. Agrogeol. julk. no 70, Helsinki.

Temple, K. L. and LeRoux, N. W. (1964). Syngenesis of sulfide ores; desorption of absorped metal ions and their precipitation as sulfides, Econ. Geology, 59 No 4 pp. $645-655$.

Manuscript received, January 19, 1968. 